\title{
Peningkatan pembelajaran ilmu pengetahuan alam melalui pendekatan sains teknologi masyarakat
}

\author{
Ratna Juita ${ }^{*}$ \\ SDN 07 Silaut Kecamatan Silaut
}

\begin{tabular}{l} 
Article Info \\
\hline Article history: \\
Received Des $30^{\text {th }}, 2020$ \\
Revised Jan $30^{\text {th }}, 2021$ \\
Accepted Feb18 $18^{\text {th }}, 2021$ \\
\hline
\end{tabular}

\section{Keyword:}

Pembelajaran IPA

Sains Teknologi Masyarakat

\begin{abstract}
Pendekatan yang digunakan adalah pendekatan kualitatif. Data penelitian diperoleh dari hasil penilaian rencana pelaksanaan pembelajaran (RPP), hasil lembaran pengamatan pelaksanaan pembelajaran dengan pendekatan STM dari aspek guru, siswa dan evaluasi. Sumber data adalah proses penerapan pendekatan STM dalam pembelajaran IPA di kelas IV. Subjek peneliti adalah guru, peneliti dan siswa kelas IV berjumlah 28 orang. Hasil penelitian adalah pembelajaran IPA dengan pendekatan STM akan menimbulkan sikap kepedulian siswa terhadap lingkungan, memotivasi siswa untuk belajar. Hal ini dibuktikan meningkatnya hasil belajar siswa yaitu siklus I ketuntasan siswa $61 \%$ dengan nilai rata-rata 74 dan siklus II ketuntasan siswa $89 \%$ dengan nilai rata-rata 84 . Berdasarkan hasil penelitian, disarankan kepada pihak berikut, (1) bagi guru hendaknya menggunakan pendekatan STM dalam pembelajaran IPA karena dapat menimbulkan sikap peduli siswa terhadap lingkungan dan meningkatkan hasil belajar siswa, (2) bagi pembaca hendaknya dapat menambah pengetahuan kepada pembaca.
\end{abstract}

(C) 2021 The Authors. Published by IICET.

This is an open access article under the CC BY-NC-SA license (https://creativecommons.org/licenses/by-nc-sa/4.0

\section{Corresponding Author:}

Ratna Juita,

SDN 07 Silaut Kecamatan Silaut

Email: ratnajuita@gmail.com

\section{Pendahuluan}

Pembelajaran IPA merupakan bagian dari pembelajaran yang dilaksanakan di sekolah dasar (SD) dan memiliki peranan penting meningkatkan mutu pendidikan untuk menghasilkan siswa yang berpikir kritis, dan tanggap dalam menanggapi isu dimasyarakat yang diakibatkan dampak perkembangan teknologi serta diharapkan mampu mengatasi masalah yang ada dilingkungannya. Hal ini dinyatakan Anna (2005:84) "Pembelajaran IPA membuat siswa menjadi tanggap terhadap perkembangan teknologi dan dapat berpikir kritis dampak positif dan negatif dari perkembangan teknologi sehingga dapat mengambil keputusan yang mensejahterakan masyarakat". Pembelajaran IPA hendaklah membuat siswa mengaplikasikan hasil belajar yang diperoleh ke lingkungan masyarakat.

Kenyataan di lapangan berdasarkan temuan di UPT SDN 07 Silaut Kecamatan Silaut, guru mengajarkan IPA pada umumnya sebatas teori tanpa siswa mengetahui bagaimana mengaplikasikan teori yang telah mereka dapat di lingkungan sekolah kedalam masyarakat jika timbul permasalahan yang berhubungan dengan sains dan teknologi. Hal ini menyebabkan pembelajaran yang didapatkan siswa jauh dari kehidupan dunia nyata yang siswa alami dalam kehidupan sehari- hari. Dalam pembelajaran guru hanya mengembangkan aspek kognitif siswa saja padahal dalam pembelajaran IPA harus dikembangkan aspek kognitif, afektif dan psikimotor. 
Untuk itu penulis mencoba menggunakan pendekatan STM dalam pemelajaran IPA karena situasi lingkungan dan sarana prasarana di UPT SDN 07 Silaut Kecamatan Silaut juga mendukung penulis untuk melakukan pembelajaran dengan pendekatan STM antara lain letak sekolah dekat dengan sumber informasi sehingga siswa mudah memperoleh informasi yang aktual seperti artikel dan buku- buku terbaru. Berdasarkan fenomena diatas penulis melakukan penelitian dengan judul "Peningkatan Pembelajaran IPA Melalui Pendekatan Sains, Teknologi dan Masyarakat (STM) dikelas IV UPT SDN 07 Silaut Kecamatan Silaut".

\section{Metode}

Penelitian ini dilaksanakan di UPT SDN 07 Silaut Kecamatan Silaut. Subjek penelitian adalah siswa kelas IV UPT SDN 07 Silaut Kecamatan Silaut yang jumlah siswanya 28 orang. Pertimbangan penulis dalam mengambil subjek tersebut sesuai dengan materi yang diajarkan saat penulis mengadakan penelitian. Waktu untuk melakukan tindakan adalah pada bulan Maret sampai Juni 2020, yang terdiri dari dua siklus yaitu siklus I dan siklus II.

Pendekatan yang peneliti gunakan adalah pendekatan kualitatif, karena sesuai dengan penelitian tindakan kelas, peneliti ingin mengamati fenomena yang terjadi di dalam kelas. Jenis penelitian ini adalah Penelitian Tindakan Kelas (PTK) atau Action Research. Menurut Ritawati (2008:11)" PTK adalah Kegiatan penelitian yang dilakukan dalam kelas untuk mencermati suatu objek dengan menggunakan cara atau metodologi tertentu untuk memperoleh data atau memperoleh informasi yang bermanfaat dalam meningkatkan kualitas guru dalam melaksanakan pembelajaran".

Sesuai dengan rumusan masalah hasil studi pendahuluan, peneliti bersama guru membuat rencana tindakan yang akan dilakukan. Tindakan itu dimulai dengan merumuskan rencana tindakan pembelajaran IPA dengan menggunakan pendekatan STM. Pelaksanaan pembelajaran IPA dengan menggunakan pendekatan STM di kelas IV SD sesuai dengan rencana pelaksanaan pembelajaran yang telah disusun. Penelitian dilakukan dalam dua siklus. Setiap siklus dilaksanakan dua kali pertemuan. Kegiatan dilakukan oleh peneliti sebagai praktisi dan guru sebagai observer. Tahap pelaksanaan dilakukan dalam dua siklus dan masing-masing dilakukan sebanyak dua kali pertemuan. Fokus tindakan pada setiap siklus berupa penggunaan pendekatan STM dalam pembelajaran IPA di kelas IV semester II.

Pengamatan pembelajaran IPA dengan menggunakan pendekatan STM di kelas IV UPT SDN 07 Silaut Kecamatan Silaut Kab. Pesisir Selatan dilaksanakan oleh guru saat pembelajaran dengan pendekatan STM berlangsung. Dalam kegiatan ini peneliti (praktisi) dan guru (observer) berusaha mengenal, mengisi instrumen semua indikator dari perubahan yang terjadi baik yang disebabkan tindakan terencana dalam pembelajaran IPA dengan pendekatan STM. Hasil pengamatan ditulis dalam bentuk lembar pengamatan. Pengamatan dilakukan secara terus menerus mulai dari siklus I sampai dengan siklus II. Pengamatan yang dilakukan pada siklus I mempengaruhi pada siklus II. Hasil pengamatan didiskusikan dengan guru dan diadakan refleksi untuk siklus berikutnya.

Refleksi dilaksanakan setiap tindakan berakhir. Dalam tahap ini peneliti dan guru serta mitra mengadakan diskusi terhadap tindakan yang baru dilakukan. Hal yang didiskusikan adalah : (1) menganalisis tindakanyang baru dilakukan, (2) mengulas dan menjelaskan perbedaan rencana dan pelaksanaan tindakan yang telah dilakukan, dan penyimpulan data yang diperoleh. Hasil refleksi digunakan untuk menyusun tindakan selanjutnya.

Data penelitian ini berupa hasil penilaian RPP, hasil pengamatan dari setiap tindakan perbaikan pembelajaran IPA dengan pendekatan STM dikelas IV SD yang diteliti. Data tersebut tentang hal- hal yang berkaitan dengan rencana pelaksanaan pembelajaran, pelaksanaan, dan hasil pembelajaran yang berupa informasi. Sumber data penelitian adalah proses pembelajaran IPA di kelas IV UPT SDN 07 Silaut Kecamatan Silaut, yang meliputi perencanaan pembelajaran, pelaksanaan pembelajaran, kegiatan evaluasi pembelajaran, prilaku guru dan siswa selama proses pembelajaran. Data diperoleh dari subjek yang diteliti dan siswa kelas IV UPT SDN 07 Silaut Kecamatan Silaut Kab. Pesisir Selatan dengan jumlah 28 orang.

Teknik pengumpulan data penelitian dilaksanakan dengan menggunakan lembaran penilaian RPP, lembaran pengamatan pelaksanaan pembelajaran dengan pendekatan STM dari aspek guru dan aspek siswa, dan evaluasi. Instrumen utama penelitian adalah peneliti sendiri, guru kelas sebagai pengamat pembelajaran dalam kelas. Peneliti sebagai instrument utama menurut Bodgan (dalam Ritawati, 2007:77) "Peneliti bertugas menyaring, menilai, menyimpulkan, dan memutuskan data yang digunakan".

Data yang diperoleh dalam penelitian dianalisis dengan menggunakan Model Analisis Data Kualitatif yakni analisis data dimulai dengan menelaah sejak pengumpulan data sampai seluruh data terkumpul. Data tersebut direduksi berdasarkan masalah yang diteliti, diikuti penyajian data dan terakhir penyimpulan. Tahap 
analisis yang demikian dilakukan berulang-ulang begitu data selesai dikumpulkan pada setiap tahap pengumpulan data dalam setiap tindakan.

Analisis data dilakukan terhadap data yang telah direduksi baik data perencanaan, pelaksanaan, maupun data evaluasi. Analisis data dilakukan dengan cara terpisah-pisah. Hal ini dimaksudkan agar dapat ditemukan berbagai informasi yang spesifik dan terfokus pada berbagai informasi yang mendukung pembelajaran dan yang menghambat pembelajaran. Dengan demikian pengembangan dan perbaikan atas berbagai kekurangan dapat dilakukan tepat pada aspek yang bersangkutan. Diharapkan berhasil, jika belum maka siklus diteruskan sampai berhasil.

\section{Hasil dan Pembahasan}

\section{Hasil Penelitian}

\section{Siklus I}

Pendekatan STM yang digunakan dalam pembelajaran kerusakan lingkungan yang disebabkan banjir disusun dan diwujudkan dalam bentuk Rencana Pelaksanaan Pembelajaran (RPP). RPP disusun berdasarkan analisis kurikulum Tingkat satuan Pendidikan (KTSP) kelas IV semester II dan secara kolaboratif antara peneliti dengan guru kelas IV UPT SDN 07 Silaut Kecamatan Silaut Kab. Pesisir Selatan. RPP disajikan dalam 2 x pertemuan yaitu $4 \times 35$ menit.

Proses pembelajaran awal adalah guru membangkitkan skemata siswa melalui kegiatan appersepsi yaitu melakukan tanya jawab tentang banjir. Proses Pembelajaran inti terdiri dari 4 langkah pembelajaran yaitu tahap invitasi, eksplorasi, solusi dan aplikasi.

Langkah kedua adalah tahap eksplorasi. Pada tahap eksplorasi guru dapat menggunakan sumber daya setempat yaitu menggunakan sumber daya alam untuk melakukan percobaan. Pada tahap invitasi, guru membagi siswa menjadi 14 kelompok dimana tiap kelompok terdiri dari 2 orang. tiap-tiap kelompok diberikan lembar kerja siswa (LKS) I dan tiap-tiap kelompok diminta untuk memperhatikan penjelasan guru tentang percobaan proses terjadinya banjir di sungai yang disebabkan timbunan sampah dan hujan deras yang akan didemonstrasikan guru dengan bantuan dua orang siswa di depan kelas. Sebelum melakukan percobaan guru menjelaskan tujuan, alat/bahan percobaan. Ketika melakukan percobaan guru mengajukan pertanyaan kepada siswa seperti apa yang menyebabkan banjir?, pada daerah yang bagaimana sering terjadi banjir?. Sambil memperhatikan percobaan, siswa dalam kelompok masing-masing mengisi LKS yang telah diberikan.

Langkah ketiga adalah tahap solusi. Pada tahap solusi diminta keikutsertaan siswa dalam mencari dan mengidentifikasi solusi untuk memecahkan masalah aktual yang dikemukakan. Tahap solusi dilakukan melalui strategi pembuat keputusan atau diskusi. Langkah yang ditempuh pada tahap solusi adalah setelah melakukan percobaan tiap-tiap kelompok diminta untuk mendiskusikan cara pencegahan banjir dan menuliskan pada lembaran pengamatan di LKS yang telah diberikan.

Langkah keempat adalah tahap aplikasi. Tahap aplikasi merupakan keterampilan proses yang dapat digunakan siswa dalam memecahkan masalah banjir sehingga membuka wawasan siswa pentingnya kesadaran akan suatu pekerjaan yang berkaitan dengan sains dan teknologi. Langkah yang dilakukan pada tahap aplikasi adalah tiap-tiap kelompok diminta untuk membuat karya teknologi sederhana yaitu banjir sesuai dengan LKS I yang telah diberikan guru.

Proses pembelajaran awal yaitu tanya jawab tentang materi pembelajaran banjir pada pertemuan I. Proses pembelajaran inti terdiri atas 4 langkah yaitu tahap invitasi, siswa memperhatikan gambar banjir yang berbeda dengan pertemuan I, kemudian guru menyampaikan isu aktual melalui artikel banjir.

Langkah kedua adalah tahap eksplorasi, membagi siswa menjadi 14 kelompok sesuai dengan pembagian kelompok pada pertemuan I. Tiap-tiap kelompok diberikan LKS II dan memperhatikan penjelasan guru tentang percobaan proses terjadinya banjir yang disebabkan longsor di tepi sungai yang akan dilaksanakan sesuai dengan LKS yang diberikan. Guru dengan bantuan dua orang siswa melakukan percobaan sambil mengajukan pertanyaan seperti mengapa terjadi banjir? dan siswa lain dalam kelompok masing-masing mengisi LKS yang telah diberikan.

Langkah ketiga adalah tahap solusi, setelah melakukan percobaan, tiap-tiap kelompok diminta mendiskusikan cara pencegahan banjir dan menuliskannya pada LKS II yang telah diberikan. Setelah diskusi dalam kelompok kemudian melaporkan hasil diskusi ke depan kelas.

Proses pembelajaran akhir adalah siswa bersama guru menyimpulkan pembelajaran yaitu cara pencegahan banjir. Setelah itu siswa secara individual megerjakan evaluasi berbentuk objektif dengan 5 butir soal yang bertujuan untuk mengukur tingkat pengetahuan siswa terhadap materi pembelajaran banjir dan esai dengan 5 
butir soal yang bertujuan untuk mengukur pemahaman siswa dan memberikan kesempatan kepada siswa untuk menjawab pertanyaan dengan pendapat sendiri.

Pembelajaran siklus I diamati oleh teman sejawat. Guru kelas mengamati berdasarkan lembaran penilaian RPP siklus I dan lembaran pengamatan karakteristik pembelajaran dengan pendekatan STM dari aspek guru dan aspek siswa dengan cara memberikan tanda ceklis $(\sqrt{ })$ berdasarkan deskriptor yang tampak baik dari pelaksana tindakan maupun dari siswa dengan kualifikasi SB, B, C, dan K.

Data hasil pengamatan lembaran penilaian RPP dan lembaran pengamatan karakteristik pembelajaran dengan pendekatan STM dari aspek guru dan aspek siswa selama mengikuti proses pembelajaran sebagai berikut: 1) Aspek Penilaian RPP. Instrumen dalam RPP lengkap yaitu soal terdiri dari pilihan ganda dan esai dengan dilengkapi kunci jawaban dan pedoman penskoran yang lengkap. Penilaian RPP cukup baik dengan persentase 71,43\% (lampiran 3) dan perlu perbaikan pada siklus II; 2) Aspek Pembelajaran dari Guru. Proses pembelajaran awal adalah guru menyampaikan tujuan pembelajaran dan membangkitkan skemata siswa melalui tanya jawab tentang banjir. Proses pembelajaran inti terdiri atas 4 tahap yaitu tahap invitasi, eksplorasi, solusi dan aplikasi.

Pada tahap invitasi guru memperagakan gambar kerusakan lingkungan yang disebabkan banjir. Namun siswa sulit untuk menjawab pertanyaan guru, hal ini disebabkan siswa kurang menyimak guru membacakan kliping banjir.

Pada tahap eksplorasi, guru membagi siswa menjadi 14 kelompok dimana tiap kelompok terdiri dari dua orang kemudian meminta bantuan dua orang siswa mendemonstrasikan percobaan proses terjadinya banjir yang disebabkan timbunan sampah dan hujan deras. Siswa lain diminta untuk memperhatikan percobaan yang akan didemonstrasikan.

Sebelum percobaan guru membagikan LKS I pada tiap kelompok dan meminta siswa berdiskusi dengan teman sebangku untuk mengisi LKS I berdasarkan percobaan yang dilakukan.

Selanjutnya pada tahap solusi, guru membagikan LKS dan meminta tiap-tiap kelompok untuk mendiskusikan cara pencegahan banjir berdasarkan LKS yang telah diberikan, kemudian meminta beberapa kelompok untuk melaporkan hasil diskusi ke depan kelas dan kelompok lain diminta menanggapi apakah hasil diskusi kelompok yang tampil benar atau salah.

Pada tahap aplikasi siswa dalam kelompok masing-masing diminta membuat karya teknologi sederhana berupa penjaring sampah berdasarkan LKS yang telah diberikan dan bimbingan guru. Hasil penjaring sampah yang dibuat siswa belum selesai, dan akan dilanjutkan pada pertemuan II. Proses pembelajaran akhir siswa bersama guru menyimpulkan materi pembelajaran tentang banjir.

Proses pembelajaran awal adalah guru membangkitkan skemata siswa melalui tanya jawab tentang materi banjir pada pertemuan I. Proses pembelajaran inti pada tahap invitasi guru memperagakan gambar kerusakan lingkungan yang disebabkan banjir. siswa sangat antusias melihat gambar banjir karena pada pertemuan I siswa sudah mempelajari sebagian dari materi banjir.

Tahap eksplorasi, guru dengan bantuan dua orang siswa mendemonstrasikan percobaan proses terjadinya banjir yang disebabkan longsor ditepi sungai.Untuk mendemonstrasikan percobaan guru meminta dua orang siswa kedepan kelas untuk membantu guru mendemonstrasikan percobaan. Siswa lain diminta untuk memperhatikan percobaan yang akan didemonstrasikan. Sebelum percobaan guru membagikan LKS II pada tiap kelompok dan meminta siswa berdiskusi dengan teman sebangku untuk mengisi LKS II berdasarkan percobaan yang dilakukan.

Selanjutnya pada tahap solusi, guru membagikan LKS II dan meminta tiap-tiap kelompok untuk mendiskusikan cara pencegahan banjir berdasarkan LKS II yang telah diberikan, kemudian meminta beberapa kelompok untuk melaporkan hasil diskusi ke depan kelas dan kelompok lain diminta menanggapi apakah hasil diskusi kelompok yang tampil benar atau salah. Beberapa kelompok sangat antusias untuk melaporkan hasil diskusi ke depan kelas. Kegiatan berdiskusi sudah berjalan dengan baik karena pada waktu kelompok melaporkan hasil diskusi ke depan kelas sudah ada kelompok lain yang menanggapi. Namun kelompok yang tampil tidak mampu menjawab pertanyaan yang diajukan temannya. Akhirnya guru yang menjawab pertanyaan yang diajukan kelompok lain. Setelah diskusi guru memberikan penjelasan materi yang belum dipahami siswa.

Pada tahap aplikasi siswa dalam kelompok masing-masing diminta melanjutkan membuat karya teknologi sederhana berupa penjaring sampah berdasarkan LKS yang telah diberikan dan bimbingan guru. 
Proses pembelajaran akhir siswa bersama guru menyimpulkan materi pembelajaran tentang tanah longsor. Setelah itu guru memberikan evaluasi secara individual berupa soal pilihan ganda berjumlah 5 butir dan esai 5 butir.

Keberhasilan evaluasi kognitif( soal) adalah 74\% (lampiran 12), keberhasilan pelaksanaan tindakan pada siklus I pertemuan I dari aspek guru adalah 65,63\% (lampiran 4). dan keberhasilan pelaksanaan tindakan pertemuan II dari aspek guru adalah 72,22\% (lampiran 6) Jadi keberhasilan tindakan pada siklus I dari aspek guru adalah 68,93\%

3) Aspek Pembelajaran dari Siswa. Dari aspek siswa, pengamat melaporkan sebagai berikut: pada proses pembelajaran awal siswa mendengarkan tujuan pembelajaran yang disampaikan guru, hal ini terlihat dari sikap siswa tenang sewaktu guru menyampaikan tujuan pembelajaran. Pada proses pembelajaran inti terdiri dari 4 tahap yaitu tahap invitasi, eksplorasi, solusi dan aplikasi.

Tahap aplikasi, siswa dalam kelompok membuat karya teknologi sederhana berupa penjaring sampah sesuai dengan LKS yang telah diberikan guru. Penjaring sampah yang dibuat belum selesai dan dilanjutkan pada pertemuan II.

Pertemuan II pengamat melaporkan sebagai berikut: pada proses pembelajaran awal siswa sudah mendengarkan tujuan pembelajaran yang disampaikan guru dengan baik karena siswa sudah mempelajari sebagian dari tujuan pembelajaran yang disampaikan. Proses pembelajaran inti terdiri dari 4 tahap yaitu tahap invitasi, eksplorasi, solusi dan aplikasi. Pada tahap invitasi, siswa antusias memperhatikan gambar banjir dan menjawab pertanyaan guru dengan baik, kemudian guru membacakan artikel banjir dan siswa menjawab pertanyaan guru dengan benar sehingga siswa dapat bercerita tentang bagaimana cara menghadapi banjir dan barang apa-apa saja yang perlu diselamatkan terlebih dahulu.

Tahap eksplorasi, dua orang siswa membantu guru mendemonstrasikan percobaan di depan kelas. Siswa lain memperhatikan percobaan dengan sikap tenang dan mengisi LKS II yang telah diberikan guru. Tahap solusi siswa berdiskusi dengan teman sebangku dan melaporkan hasil diskusi ke depan kelas. Kegiatan berdiskusi sudah berjalan dengan baik karena pada waktu kelompok melaporkan hasil diskusi ke depan kelas sudah ada kelompok lain yang menanggapi, namun kelompok yang tampil tidak mampu menjawab pertanyaan yang diajukan temannya. Akhir diskusi guru memberikan penjelasan materi yang belum dipahami siswa.

Keberhasilan pelaksanaan tindakan siklus I pertemuan I dari aspek siswa adalah 62,5\% (lampiran 5), keberhasilan pelaksanaan tindakan siklus I pertemuan II dari aspek siswa adalah 69,44\% (lampiran 7). Keberhasilan pelaksanaan tindakan siklus I dari aspek siswa adalah 65,97\%.

Berdasarkan uraian di atas dapat disimpulkan bahwa siklus I belum memperoleh hasil yang memuaskan. Keberhasilan persentase yang diharapkan baik. Dari hasil diskusi peneliti dengan kolaborator perlu dilanjutkan ke siklus II. Akan direncanakan dan dilaksanakan dengan baik.

Pada tahap eksplorasi berdasarkan kolaborasi peneliti dengan guru kelas ditemui siswa berebutan untuk membantu guru mendemonstrasikan percobaan sehingga suasana kelas menjadi ribut disebabkan guru kurang menguasai siswa dalam kelas. Untuk itu pada siklus II guru harus mampu menguasai kelas agar anak tidak meribut dengan cara siswa disuruh tunjuk tangan dengan tertib untuk membantu guru mendemonstarsikan percobaan. Selain itu dalam percobaan siswa sulit untuk menjawab pertanyaan guru yang berkaitan dengan percobaan maka siklus II guru harus lebih memperjelas pertanyaan dan memakai bahasa yang mudah dimengerti siswa.

Tahap solusi, tiap-tiap kelompok antusias untuk melaporkan hasil diskusi ke depan kelas, namun setelah hasil diskusi dilaporkan tidak satupun kelompok lain yang menanggapi. Hal ini disebabkan siswa tidak terbiasa berdiskusi dengan baik, guru kurang menjelaskan bagaimana memberikan tanggapan dalam berdiskusi dan siswa kurang memahami materi pembelajaran tentang banjir sehingga siswa kurang mampu menanggapi hasil diskusi kelompok yang tampil di depan kelas. Berdasarkan kolaborasi peneliti dengan guru kelas untuk siklus II sebaiknya dalam diskusi guru membimbing siswa dengan baik bagaimana cara menanggapi hasil diskusi, guru lebih memperjelas materi pembelajaran misalnya dalam melakukan percobaan harus dilaksanakan dengan tepat dan memakai bahasa yang mudah dimengerti siswa. Setelah percobaan guru lebih mengulas hasil percobaan yang telah didapat sehingga siswa lebih memahami materi pembelajaran dan mampu memberikan pertanyaan atau menanggapi hasil diskusi dengan baik.

Pada tahap aplikasi hasil karya teknologi sederhana berupa penjaring sampah kurang rapi karena sulitnya siswa untuk memotong kawat. Kemudian dalam mengikat kawat dengan dawai juga kurang rapi karena siswa sering memukul dawai yang telah diikat pada kawat dengan batu akibatnya dawai yang diikat tidak rapi. 
Berdasarkan kolaborasi peneliti dengan guru kelas sebaiknya tahap aplikasi untuk siklus II guru lebih membimbing siswa dalam membuat karya teknologi sederhana.

Hasil tes siklus I menunjukkan jawaban siswa sudah sesuai dengan yang diharapkan, namun masih ada beberapa orang siswa yang belum mampu menjawab soal sesuai dengan yang diharapkan. Untuk lebih jelasnya dapat dilihat pada lampiran 12 secara umum hasil belajar siswa pada siklus I adalah:

Tabel 1. Hasil Tes Siklus 1

\begin{tabular}{cccccc}
\hline Banyak & Nilai & Nilai & Nilai Rata- & Banyak Siswa yang & \% ketuntasan \\
Siswa & Terendah & Tertinggi & rata & Tuntas & siswa \\
28 & 44 & 100 & 74 & 17 & $61 \%$ \\
\hline
\end{tabular}

Pada siklus 1 hasil yang dicapai sudah baik, namun masih ada beberapa siswa yang belum tuntas sehingga peneliti merasa pembelajaran dengan pendekatan STM pada materi kerusakan lingkungan belum berhasil sesuai dengan yang diharapkan. Peneliti berkeinginan pada langkah-langkah pendekatan STM siswa lebih aktif dalam pembelajaran seperti aktif dalam mengajukan pertanyaan, mampu berdiskusi dan menjawab pertanyaan dengan baik. Berdasarkan kolaborasi peneliti dengan guru kelas, pembelajaran perlu dilanjutkan kesiklus II dengan rencana perbaikan semua kenadala yang ditemui pada siklus 1 akan diperbaiki pada siklus II.

\section{Siklus II}

Pembelajaran dengan pendekatan STM pada siklus II diwujudkan dalam bentuk RPP yang dibuat kolaboratif antara peneliti dan guru dengan memperbaiki kelemahan pada siklus I. Proses pembelajaran yang direncanakan adalah proses pembelajaran awal guru membangkitkan skemata siswa dengan tanya jawab tentang gambar tanah longsor.

Pada tahap eksplorasi, guru membagi siswa menjadi 14 kelompok sesuai dengan pembagian kelompok pada siklus I dan membagikan LKS pada tiap-tiap kelompok kemudian meminta dua orang siswa kedepan kelas untuk membantu guru mendemonstrasikan percobaan. Guru mengajukan pertanyaan ketika percobaan berusaha untuk lebih memfokuskan pertanyaan pada materi pembelajaran sehingga siswa dapat menjawab pertanyaan dengan benar. Tahap solusi tiap-tiap kelompok berdiskusi berdasarkan LKS yang diberikan guru. Tahap ini guru lebih membimbing siswa dalam berdiskusi dan menanggapi kelompok yang melaporkan hasil diskusi sehingga diharapkan diskusi berjalan dengan baik.

Tahap aplikasi tiap-tiap kelompok membuat karya teknologi sederhana yaitu balok penyangga. Balok penyangga dapat dibuat dengan baik sesuai dengan yang diharapkan. Proses pembelajaran akhir guru memberikan tes berupa soal pilihan ganda 5 butir dan esai 5 butir. Proses pembelajaran awal guru membangkitkan skemata siswa dengan tanya jawab tentang tanah longsor. Proses pembelajaran inti terdiri dari tahap invitasi, eksplorasi, solusi dan aplikasi.

Tahap eksplorasi merupakan mempelajari masalah yang dapat dilakukan dengan sumber daya alam setempat yaitu berupa alat-alat percobaan tanah longsor. Setelah percobaan tiap-tiap kelompok diminta mengisi LKS III yang telah diberikan.

Tahap solusi merupakan keaktifan siswa dalam mencari dan megidentifikasi solusi untuk memecahkan masalah tanah longsor yang dilakukan melalui diskusi atau strategi pembuat keputusan. Pada tahap solusi guru membagikan LKS III dan meminta siswa untuk mendiskusikan bagaimana cara mencegah tanah longsor. Hasil diskusi pada LKS III sudah hampir betul semua karena siswa sudah memahami materi pembelajaran dengan sungguh-sungguh memperhatikan percobaan dan diskusi cara pencegahan tanah longsor.

Tahap aplikasi merupakan suatu keterampilan proses yang dapat diaplikasikan siswa dalam memecahkan masalah tanah longsor sehingga membuka wawasan tentang pentingnya suatu pekerjaan yang dapat mencegah tanah longsor. Pada tahap aplikasi guru meminta siswa membuat karya teknologi sederhana yaitu balok penyangga. Guru membimbing siswa membuat balok penyangga sesuai dengan LKS yang telah diberikan. Karena keterbatasan waktu pembuatan penjaring sampah dilanjutkan pada pertemuan II. Dengan membuat balok penyangga siswa memperoleh pengalaman untuk memecahkan masalah yang ada di lingkungannya.

Pada pertemuan II merupakan kelanjutan materi pada pertemuan I. Pada proses pembelajaran awal guru tanya jawab tentang materi tanah longsor pada pertemuan I. Proses pembelajaran inti tahap invitasi yaitu guru memajangkan gambar tentang tanah longsor dan tanya jawab tentang tanah longsor. 
Tahap eksplorasi, guru meminta dua orang siswa untuk membantu guru mendemonstrasikan percobaan tentang proses terjadinya tanah longsor yang disebabkan gempa. Ketika melakukan percobaan guru mengajukan pertanyaan dan siswa sudah mampu menjawab pertanyaan guru dengan benar karena siswa serius memperhatikan percobaan. Setelah percobaan siswa mengisi LKS IV yang telah diberikan guru.

Tahap solusi, guru meminta siswa dalam kelompok masing-masing mendiskusikan cara pencegahan tanah longsor berdasarkan percobaan yang telah dilakukan. Siswa aktif dalam melaporkan hasil diskusi, kelompok lain sudah mengajukan pertanyaan dan menanggapi hasil diskusi kelompok yang tampil. Kelompok yang tampil sudah mampu menjawab pertanyaan kelompok lain. Tahap aplikasi adalah melanjutkan membuat balok penyangga. Tiap-tiap kelompok membuat balok penyangga dengan baik. Kemudian guru bersama siswa melakukan pembuktian penggunaan balok penyangga dengan melakukan percobaan terjadinya tanah longsor pada daerah perbukitan yang telah disusun balok penyangga pada perbukitan tersebut.

Proses pembelajaran akhir adalah siswa bersama guru menyimpulkan pembelajaran dan memberikan evaluasi berupa soal pilihan ganda 5 butir dan esai 5 butir. Hasil tes akhir menggambarkan subjek penelitian sudah menguasai dengan baik materi cara pencegahan kerusakan lingkungan yang disebabkan tanah longsor. Siswa memperoleh skor diatas $75 \%, 3$ orang yang mendapat skor dibawah $75 \%$ dari hasil rata-rata menyimpulkan bahwa penelitian telah mencapai target yaitu $84 \%$. Data hasil belajar siswa siklus II dan data nilai ketuntasan siswa terdapat pada lampiran 25.

\section{Aspek Penilaian RPP}

(1) Rumusan tujuan pembelajaran jelas, tidak menimbulkan penafsiran ganda, lengkap (memenuhi $\mathrm{A}=$ audience, $\mathrm{B}=$ behavior, $\mathrm{C}=$ condition, dan $\mathrm{D}=$ degree) serta urutan dimulai dari yang sukar ke yang mudah karena dimulai dari membuat karya teknologi sederhana, mendemonstrasikan percobaan dan mendiskusikan cara pencegahan tanah longsor, (2) Pemilihan materi ajar sesuai dengan tujuan pembelajaran, lingkungan yang tersedia mudah untuk mendapatkan berita aktual baik dari koran maupun artikel. bahan yang akan diajarkan guru kelas sesuai dengan bahan pelaksanaan tindakan peneliti, (3) Pengorganisasian materi ajar adalah pengembangan materi cukup luas, karena selain dari buku paket juga didapat dari koran dan artikel, (4) Pemilihan sumber/media pembelajaran berupa gambar tanah longsor, kliping dan artikel sesuai dengan materi pembelajaran tanah longsor dan sesuai dengan lingkungan siswa yang mudah untuk mendapatkan sumber belajar, (5) Langkah-langkah pembelajaran dalam RPP jelas dan berurut yaitu terdiri atas proses pembelajaran awal, inti, dan akhir sehingga sesuai dengan alokasi waktu yaitu 2 kali pertemuan (140 menit), (6) Teknik pembelajaran dengan menggunakan pendekatan STM sesuai dengan tujuan pembelajaran dan materi pembelajaran yaitu tentang pencegahan tanah longsor, (7) instrumen dalam RPP lengkap yaitu soal terdiri dari pilihan ganda dan esai dengan dilengkapi kunci jawaban dan pedoman penskoran yang lengkap. Penilaian RPP baik dengan persentase 85,71\% ( lampiran 16).

\section{Aspek Pembelajaran dari Guru}

Proses pembelajarn awal dapat terlaksana dengan baik karena guru sudah melaksanakan sesuai dengan perencanaan. Di sini siswa sangat antusias menjawab pertanyaan guru karena siswa membaca langsung kliping tentang tanah longsor dan beberapa orang siswa menanyakan isi kliping yang tidak dimengerti oleh siswa itu. Namun masih ada beberapa orang siswa yang kurang aktif baik menjawab pertanyaan guru maupun memberikan pertanyaan.

Pada Tahap eksplorasi guru telah melaksanakan sesuai perencanaan yaitu membagi siswa menjadi 14 kelompok dimana tiap kelompok terdiri dari 2 orang dan meminta dua orang siswa membantu guru mendemonstrasikan percobaan tentang proses terjadinya tanah longsor yang disebabkan hujan deras. Ketika melakukan percobaan guru lebih memfokuskan pertanyaan pada materi pembelajaran sehingga siswa dapat menjawab pertanyaan guru dengan baik.

Tahap solusi, guru meminta masing-masing kelompok mendiskusikan cara pencegahan tanah longsor berdasarkan percobaan yang telah dilakukan dan LKS III yang telah dibagikan. Pada saat melaporkan hasil diskusi hampir semua kelompok yang mengajukan untuk melaporkan hasil diskusi, namun karena keterbatasan waktu guru hanya meminta 8 kelompok dan kelompok lain diminta untuk mengajukan pertanyaan atau menanggapi kelompok yang tampil. Dalam hal memberikan tanggapan hampir semua kelompok yang menanggapi kelompok yang tampil. Dengan bimbingan guru kelompok yang tampil dapat menjawab dengan baik pertanyaan atau tanggapan dari kelompok lain.

Tahap aplikasi, guru membimbing siswa membuat karya teknologi sederhana yaitu balok penyangga. Karya teknologi yang dibuat belum selesai akan dilanjutkan pada pertemuan II. Pada proses pembelajaran akhir siswa bersama guru menyimpulkan pembelajaran. Keberhasilan pelaksanaan tindakan dari aspek guru pada siklus II pertemuan I adalah 81,25\% (lampiran 17) 
Keberhasilan pelaksanaan tindakan siklus II pertemuan II dari aspek guru adalah 83,33\%. Keberhasilan pelaksanaan tindakan pada siklus II dari aspek guru adalah $82,29 \%$ Evaluasi proses (afektif dan psikomotor) telah mencapai keberhasilan. Lebih jelasnya dapat dilihat pada lampiran 21 dan 22, persentase evaluasi hasil/kognitif adalah 84\% (lampiran 25).

\section{Aspek Pembelajaran dari Siswa}

Tahap aplikasi tiap-tiap kelompok dengan bimbingan guru membuat balok penyangga dengan tenang. Balok penyangga yang dibuat belum selesai dan akan dilanjutkan pada pertemuan II. Pada proses pembelajaran akhir siswa bersama guru menyimpulkan pembelajaran. Keberhasilan pelaksanaan tindakan siklus II pertemuan I dari aspek siswa adalah 78,13\% (lampiran 18)

Proses pembelajaran akhir siswa bersama guru menyimpulkan pembelajaran dan mengerjakan evaluasi berupa soal pilihan ganda 5 butir dan esai 5 butir. Keberhasilan pelaksanaan tindakan dari aspek siswa siklus II pertemuan II adalah 83,33\% (lampiran 20). Jadi keberhasilan pelaksanaan tindakan siklus II dari aspek siswa adalah $80,73 \%$ Siklus II telah menunjukkan keberhasilan, hal ini dapat maka berdasarkan diskusi peneliti dengan guru kelas maka penelitian cukup sampai disini.

Berdasarkan pengamatan peneliti dan observer pada siklus II, pelaksanaan penelitian sudah berjalan sesuai dengan yang diharapkan karena siswa sudah terbiasa melakukan percobaan, diskusi dengan pendekatan STM yang telah digunakan. Secaar umum hasil tes siklus II adalah:

Tabel 2. Hasil Tes Siklus II

\begin{tabular}{cccccc}
\hline Banyak & Nilai & Nilai & Nilai Rata- & Banyak Siswa yang & $\%$ ketuntasan siswa \\
Siswa & Terendah & Tertinggi & rata & Tuntas & \\
28 & 56 & 100 & 84 & 25 & $89 \%$ \\
\hline
\end{tabular}

Dari 28 orang siswa yang mengikuti tes pada siklus II terdapat 25 orang yang mendapatkan nilai 75 keatas sesuai dengan standar keberhasilan yang ditetapkan yaitu 75 , sehingga siswa itu dikatakan tuntas dalam belajar, dan ada 3 orang siswa yang tidak tuntas. Hasil belajar dan ketuntasan yang diperoleh pada siklus II dapat dilihat pada lampiran 25

\section{Pembahasan \\ Pembahasan Siklus I}

Hasil penelitian siklus I diperoleh pembelajaran dengan pendekatan STM belum terlaksana sesuai dengan yang diharapkan, karena perencanaan belum sesuai dengan pelaksanaan, hal ini dapat dilihat pada tahap invitasi siswa kurang mampu menjawab pertanyaan guru tentang kliping yang telah dibacakan guru. Kemudian pada tahap eksplorasi siswa kurang merespon pertanyaan guru ketika melakukan percobaan, tahap solusi siswa tidak mengajukan pertanyaan atau menanggapi kelompok yang melaporkan hasil diskusi didepan kelas dan tahap aplikasi suasana kelas agak ribut karena banyak kelompok yang tidak membawa peralatan yang lengkap sehingga meminjam peralatan teman.

Berdasarkan kolaborasi peneliti dengan teman sejawat, penyebab belum terlaksananya pendekaatn STM pada siklus I adalah pada tahap invitasi siswa tidak mampu menjawab pertanyaan guru tentang kliping karena siswa kurang menyimak kliping yang dibacakan guru sebaiknya kliping dibaca oleh masing-masing siswa sehingga siswa lebih mengerti isi kliping yang telah dibaca dan dapat menjawab pertanyaan guru dan pada tahap eksplorasi sebaiknya guru lebih memfokuskan pertanyaan pada materi pembelajaran dan menggunakan bahasa yang mudah dimengerti oleh siswa. Selanjutnya pada tahap solusi guru harus dapat membimbing siswa untuk berdiskusi dengan baik sehingga siswa mampu mengajukan pertanyaan dan memberikan tanggapan dalam diskusi sehingga siswa lebih memahami materi pembelajaran IPA dengan menggunakan pendekatan STM karena pembelajaran dengan menggunakan pendekatan STM diharapkan siswa peduli terhadap lingkungan dan dapat memecahkan masalah dalam kehidupan sehari-hari yang berkaitan dengan sains dan teknologi. Pada tahap solusi guru harus lebih mampu mengontrol situasi kelas dan membimbing siswa dalam membuat karya teknologi sederhana.

Berdasarkan hasil penelitian dan analisis data pada siklus I diketahui bahwa persentase perencanaan (RPP) adalah $71,43 \%$, persentase pelaksanaan dari aspek guru 68,93\%, persentase pelaksanaan dari aspek siswa $65,97 \%$, evaluasi proses (afektif dan psikomotor) belum menunjukkan keberhasilan dan dapat dilihat pada lampiran 8 dan 9 dan evaluasi kognitif (hasil) 74\%. Oleh karena itu, peneliti melakukan siklus II agar tujuan yang diharapkan dalam pembelajaran dengan pendekatan STM dapat tercapai.

\section{Pembahasan Siklus II}

Pembelajaran dengan pendekatan STM pada siklus II sudah terlaksana sesuai dengan yang diharapkan karena pelaksanaan sudah sesuai dengan perencanaan. Pada proses pembelajaran awal siswa sudah mendengarkan 
tujuan pembelajaran yang disampikan guru dengan sikap tenang dan serius. Pada tahap invitasi siswa sudah aktif dalam menjawab pertanyaan guru, siswa sudah memahami isi kliping atau artikel tentang materi pembelajaran sehingga siswa sudah mampu menjawab pertanyaan guru tentang materi pembelajaran.Tahap eksplorasi siswa sudah memahami percobaan, hal ini terlihat siswa sudah mampu menjawab pertanyaan guru yang berkaitan dengan percobaaan karena dalam pembelajaran IPA guru harus mampu menguasai materi yang terkait dengan konsep sains dan proses sains. Hal ini dinyatakan Anna (2005:137) " guru perlu menguasai materi yang terkait dengan konsep dan proses sains yang dikaji selama pembelajaran" .Tahap solusi guru sudah mampu membimbing siswa untuk berdiskusi dengan baik sehingga siswa sudah mampu memberikan tanggapan dalam berdiskusi. Pada tahap aplikasi siswa sudah bekerja dengan baik dalam membuat karya teknologi sederhana. Pada siklus II guru dapat menyampaikan materi pembelajaran dengan baik sehingga mampu memahami materi dengan baik.

Bagi siswa yang belum memahami materi pembelajaran, guru memberikan pertanyaan dan umpan balik sehingga siswa termotivasi untuk belajar. Motivasi guru sangat berpengaruh pada sikap siswa dalam belajar karena dengan motivasi guru siswa lebih semangat dalam belajar. Hal ini dinyatakan Sardiman (2006:77) "memberikan motivasi pada siswa berarti menggerakkan siswa untuk melakukan sesuatu atau ingin melakukan sesuatu sehingga siswa ingin melakukan sesuatu dalam pembelajaran".

Pembelajaran dengan pendekatan STM akan memuat materi yang berhubungan dengan masalah yang terjadi dilingkungan siswa. Dengan menggunakan pendekatan STM pada materi kerusakan lingkungan yang disebabkan banjir dan tanah longsor diharapkan siswa mampu menerapkan cara pencegahan banjir dan tanah longsor dalam lingkungan tempat tinggal siswa karena ada sebagian siswa yang rumahnya ditepi sungai atau di daerah perbukitan. Dengan materi pembelajaran kerusakan lingkungan yang disebabkan banjir dan tanah longsor siswa akan memperoleh sesuatu yang berguna dalam kehidupannya.

Melalui pendekatan STM siswa akan tertarik dan termotivasi untuk belajar karena siswa mendapatkan sesuatu yang berguna dalam kehidupan yang berhubungan dengan masalah lingkungan yang muncul dimasyarakat. Hal ini berarti pendekatan STM sangat baik diterapkan dalam pembelajaran IPA yang materinya berkaitan dengan masalah-masalah yang berhubungan dengan sains dan teknologi.Dari analisis data penelitian siklus II telah mencapai keberhasilan yang baik yaitu persentase perencanaan (RPP) $85,71 \%$, persentase pelaksanaan pembelajaran dari aspek guru $82,29 \%$, persentase pelaksanaan pembelajaran dari aspek siswa $80,73 \%$ dan keberhasilan evaluasi afektif dapat dilihat pada lampiran 21, kognitif (hasil) $84 \%$, psikomotor pada lampiran 22 . Berdasarkan hasil yang diperoleh pada siklus II, pelaksanaan siklus II telah terlaksana dengan baik dan guru telah berhasil menggunakan pendekatan STM dalam pembelajaran IPA dengan materi kerusakan lingkungan yang disebabkan tanah longsor dan banjir di UPT SDN 07 Silaut Kecamatan Silaut Kab. Pesisir Selatan.

\section{Simpulan}

Berdasarkan hasil penelitian dan pembahasan peningkatan pembelajaran IPA dengan pendekatan STM dapat disimpulkan pembelajaran dengan pendekatan STM dapat meningkatkan keinginan siswa untuk mengetahui masalah-masalah lingkungan yang berhubungan dengan sains, teknologi dan kesejahteraan masyarakat sehingga siswa tertarik untuk mengetahui bagaimana cara mencegah masalah yang ada di lingkungan serta dapat menimbulkan sikap kepedulian siswa terhadap lingkungan dan memotivasi siswa untuk belajar karena sesuai dengan lingkungan dan kehidupan sehari-hari siswa. Melalui diskusi siswa dapat mengemukakan pendapat sehingga akan melatih keberanian siswa dalam pembelajaran. Selain itu siswa dapat merancang karya teknologi sederhana untuk mencegah kerusakan lingkungan yang disebabkan tanah longsor dan banjir.

\section{Referensi}

Aderusliana. 2007. Konsep Dasar Evaluasi Hasil Belajar (http://aderusliana.workpress.com/2007/11/05/ konsep-dasar-evaluasi-hasil-belajar/ diakses tanggal 2 mei 2020)

Anna Poedjiaji. 2005. Sains Teknologi Masyarakat. Bandung: PT Remaja Rosda Karya

BSNP. 2006. Panduan Penyusunan Kurikulum Tingkat Satuan Pendidikan Jenjang Pendidikan Dasar dan Menengah. Jakarta: BSNP

Choiril Azmiyawati. 2008. IPA 5 Saling Temas untuk V SD. Jakarta: Depdiknas

Depdiknas. 2006. Kurikulum Tingkat Satuan Pendidikan. Jakarta: BNSP

Heri Sulistiyanto dan Edy Wiyono. 2008. Ilmu Pengetahuan Alam untuk SD dan MI Kelas V. Jakarta: Depdiknas

Maslichah Asy'ari. 2006. Penerapan Pendekatan Sains- Teknologi- Masyarakat dalam Pembelajaran Sains di SD. Yogyakarta: Universitas Sanata Dharma 
Martinis Yamin. 2007. Kiat Membelajarkan Siswa. Jakarta: Gaung Persada Press

Nuryani R. 2005. Strategi Belajar Mengajarkan biologi. Malang: Universitas Negeri Malang

Ritawati Mahyuddin, dan Yetti Ariani. 2008. Hand out Mata Kuliah Metodologi Penelitian Tindakan Kelas. Padang: UNP

Suharsimi Arikunto, dkk. 2006. Penelitian Tindakan Kelas. Jakarta: Bumi Aksara

Syamsuarlis. 2008. Upaya Meningkatkan Pemahaman Konsep dan Hasil Belajar IPA Melalui Pendekatan Kontekstual pada Siswa Kelas V SD Negeri 06 Teluk Bayur Padang. Yogyakarta: Universitas Negeri Yogyakarta

Wina Sanjaya. 2008. Strategi Pembelajaran Berorientasi Standar Proses Pendidikan. Jakarta: Kencana Prenada Media Grup. 